\title{
Evaluation of ground water quality near Chandi Devi bridge solid waste dumping site at Hairdwar city, (Uttarakhand), India : A case study
}

\section{Sandeep Gupta*}

Department of Zoology and Environmental Science, Gurukula Kangri University, Hardwar-249404 (Uttarakhand), India

Present address: Ajay Kumar Garg Engineering College, Ghaziabad-201013 (Uttar Pradesh), India

A. K. Chopra

Department of Zoology and Environmental Science, Gurukula Kangri University, Hardwar-249404 (Uttarakhand), India

*Corresponding author. E-mail : sandeesan@gmail.com

\begin{abstract}
The present study observed groundwater quality around Chandi Devi bridge open dumping site at Hardwar (Uttarakhand), India. Five experimental sites viz. sites 2,3 and 5 (hand pumps) and two sites 4,6 (tubewells) within the vicinity of the dumpsite and a reference site viz. site 1 (hand pump) (Bilkeshwar temple) as a control about 5000 meter away, were selected to ascertain the influence of solid waste dumping on groundwater quality around the area. The study showed that physicochemical parameters viz temperature, colour, turbidity, $\mathrm{pH}$, hardness, $\mathrm{BOD}, \mathrm{COD}$, fluoride and heavy metals (lead and iron) of the ground water near the dumping sites-2,3,4,5,6 were higher than their counterpart parameters of the ground water at control site. However, arsenic was not detected in any sample of all the sites. The parameters viz., colour (2.08-3.49 hazen), turbidity (3.05-5.35 NTU), odour (agreeable), $\mathrm{pH}$ (7.46-7.80),fluoride (0.10-0.38 ppm), lead (0.00-0.032 ppm), iron (0.01-0.03 $\mathrm{ppm}$ ) of ground water of all experimental sites were within permissible limits while the parameters BOD (3.73-3.21 ppm), hardness (240.41-203.15 ppm) at site-2, site-3 and DO (5.38$6.28 \mathrm{ppm}$ ) of all experimental sites were not found within permissible limits as prescribed by Bureau of Indian standards (2012). Although water was safe for drinking which may be due to higher infiltration rate of river Ganga and Eastern Ganga Canal water but higher value of temperature $\left({ }^{\circ} \mathrm{C}\right)$, colour (hazen), turbidity $(\mathrm{ppm})$, hardness (ppm), BOD (ppm), COD (ppm) fluoride (ppm), iron (ppm) and lead (ppm) at site- 2 was quite alarming. The study would help in making public awareness for waste sorting, adopting green technology and to predict level of contaminants in ground water produced by land filling dumping site.
\end{abstract}

Keywords: Ground water, Chandighat duumping site, Haridwar, Heavy metals, Physico-chemical parameters

\section{INTRODUCTION}

Ground water is a precious renewable natural resource, which has been exploited by man since centuries and is considered to be least polluted as compared to other inland water resource. Now in the era of economic growth ground water is becoming contaminated with hazardous substances from thousands of legally and illegally constructed and operated landfills surface impoundments in septic systems. As an advent of population growth and climate change, presently in most countries more than half of the extracted groundwater is used for meeting domestic needs, whereas globally $25 \%-40 \%$ is used as drinking water indicating that the demand for clean groundwater has already grown dramatically (NGSA, 2016).

\section{Article Info}

DOI:10.31018/jans.v10i2.1767 Received: January 6, 2018

Revised: April 4, 2018

Accepted: May 3, 2018

\section{How to Cite}

Gupta, S. and Chopra, A.K.(2018). Evaluation of ground water quality near Chandi Devi bridge solid waste dumping site at Hairdwar city, (Uttarakhand), India : A case study. Journal of Applied and Natural Science, 10(2): 681 - 689 
inappropriate waste management and disposal practices (Dermatas and Panagiotakis, 2012). Geogenic groundwater pollution for arsenic contamination problem in India and Bangladesh, or the hexavalent chromium contamination in California, Italy, Greece, and elsewhere, is exclusively related to the geochemical background of rock and soil, which feeds groundwater with heavy metals and these are capable of posing significant adverse effects to humans and environment (Dermatas et al., 2015). In biotic perspective, heavy metals enter into living organisms through food, water or frequent contact to emission sources, though few of them serve as vital micro nutrients for living beings but at higher concentration it can lead to severe poisoning (Lenntech 2004). In recent past, Soujanya and Kamble (2016) showed characterization of leachate and its effects on ground water quality at Telangana in India and Karthika et al. (2018) studied the ground water quality near industrial area sites at Tamilnadu and Krcmar, et al. (2018) studied the effect of municipal landfill pollution on soil and shallow groundwater in Subotica, Serbia. The present study was undertaken to analyze effect of wastedisposal on the groundwater quality of the area near Chandi Devi bridge solid waste dumping site at Hairdwar city (Uttarakhand), India.

\section{MATERIALS AND METHODS}

Study area: Hardwar is a holy place located at $29^{\circ} 56^{\prime} 52^{\prime \prime} \mathrm{N} 78^{\circ} 09^{\prime} 36^{\prime \prime} \mathrm{E}$ where people come not only from India but also from abroad to perform various socio-religious rituals almost throughout the year. The total population of Hardwar city is 2,28,832 as per 2011 census (www.census2011.co.in/city.php) having a city area $2,360 \mathrm{~km}^{2}$. The population of Hardwar city get increased during the Hindus' festivals time by tourist and pilgrims who left bulk amount of municipal waste here. The central Hardwar area (Harki pauri to Kankhal) always remained packed with the tourist and generated waste was being dumped near Chandi bridge municipal dumping site which extended towards N-W direction of Chandi bridge. The area of Experimental sites covered approx. $20000 \mathrm{mt}^{2}$. Sites-2, 3, 5 (Handpump water) and sites-4, 6 (tubewell water) were selected as Experimental sites and Bilkeshawar temple (Handpump) was selected as control site. Site-2 water source was located in S-E direction and $60 \mathrm{mt}$ far from dumping area. Site-3 was located in south direction and $122 \mathrm{mt}$. far. Site-4 was located in S-E direction and $91 \mathrm{mt}$. far, Site- 5 was in south direction and $240 \mathrm{mt}$. far. Site6 was located in south direction and $260 \mathrm{mt}$. far from the dumping site. The control site (site-1 Bilkeshwar temple) was located S-E direction and 5000 meter far from the experimental sites (Fig.1). Methodology: The ground water samples

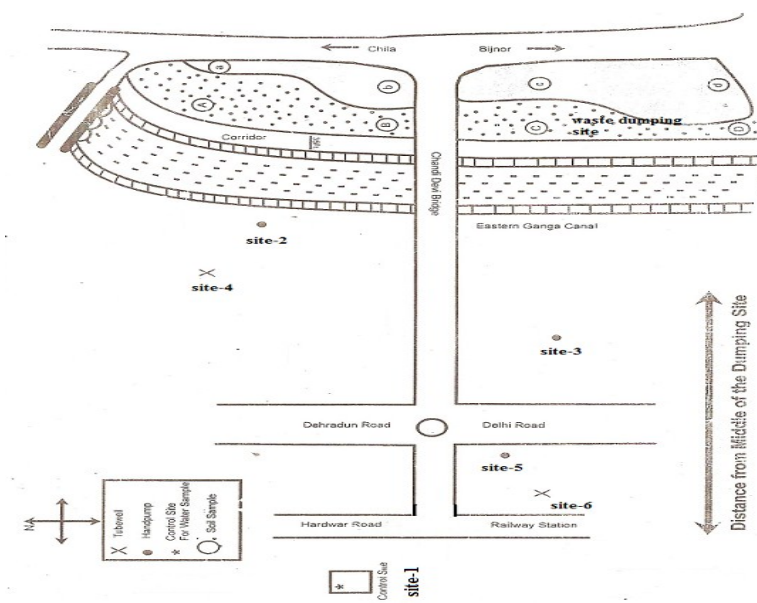

Fig. 1. Study area showing different sampling sites of groundwater near Chandi Devi bridge dumping area and control site (near Bilkeshwar temple), Haridwar city (Uttrakhand).

$(500 \mathrm{ml}$.$) were collected from the sources (4 hand$ pumps and 2 tube wells) in plastic canes from the area of dumping site during 2005-2007 from January to December by avoiding sampling during rainfall period. At a time four water samples were taken monthly from each site i.e ( $4 \times 6=24$ samples) for analysis. Some of the parameters were determined immediately at sampling sites viz. temperature $\left({ }^{\circ} \mathrm{C}\right), \mathrm{pH}$ while for dissolved oxygen (ppm) and biochemical oxygen demand (ppm), samples were collected in $300 \mathrm{ml}$ sterilized BOD bottles. The bottles were filled completely with sample water up to the rim and stopper was placed to avoid any kind of air bubble inside it. DO was immediately fixed by adding $2 \mathrm{ml}$ alkaline potassium iodide and manganese sulphate $\left(\mathrm{MnSO}_{4}\right)$ at sampling spot. While the sample for BOD was incubated for 5 days in BOD incubator at $20^{\circ} \mathrm{C}$ in the laboratory. For rest parameters like colour (hazen), turbidity (NTU), odour, hardness (ppm), fluoride (ppm), standard methods were used as per APHA (2005). The samples of groundwater for the analysis of heavy metals (arsenic, lead, iron) were stored in refrigerator at $4^{\circ} \mathrm{C}$ and acidified with concentrated $\mathrm{HNO}_{3}(5 \mathrm{ml} / \mathrm{l} \mathrm{ml}$ of water sample to reduce the $\mathrm{pH}$ of the sample, $\mathrm{pH}>2.0$ ). The total metal contents were determined by digesting 200 $\mathrm{ml}$ of sample with a mixture of concentrated $\mathrm{HNO}_{3}$ and $\mathrm{HClO}_{4}$ acid $(10 \mathrm{ml}+2 \mathrm{ml})$. The digested samples were filtered through Whatman filter No. 42 and final volume was made $10 \mathrm{ml}$ with $0.1 \mathrm{~N}$ $\mathrm{HNO}_{3}$ and analyzed for heavy metals using AAS (Model ECIL-4129) using the method as prescribed by APHA (2005).

\section{RESULTS AND DISCUSSION}

The physicochemical parameters of the ground water quality of different sites (site-2 to site-6) of Chandidevi bridge dumping site and that of con- 
Gupta S. and Chopra A.K. / J. Appl. \& Nat. Sci. 10 (2): 681 - 689 (2018)

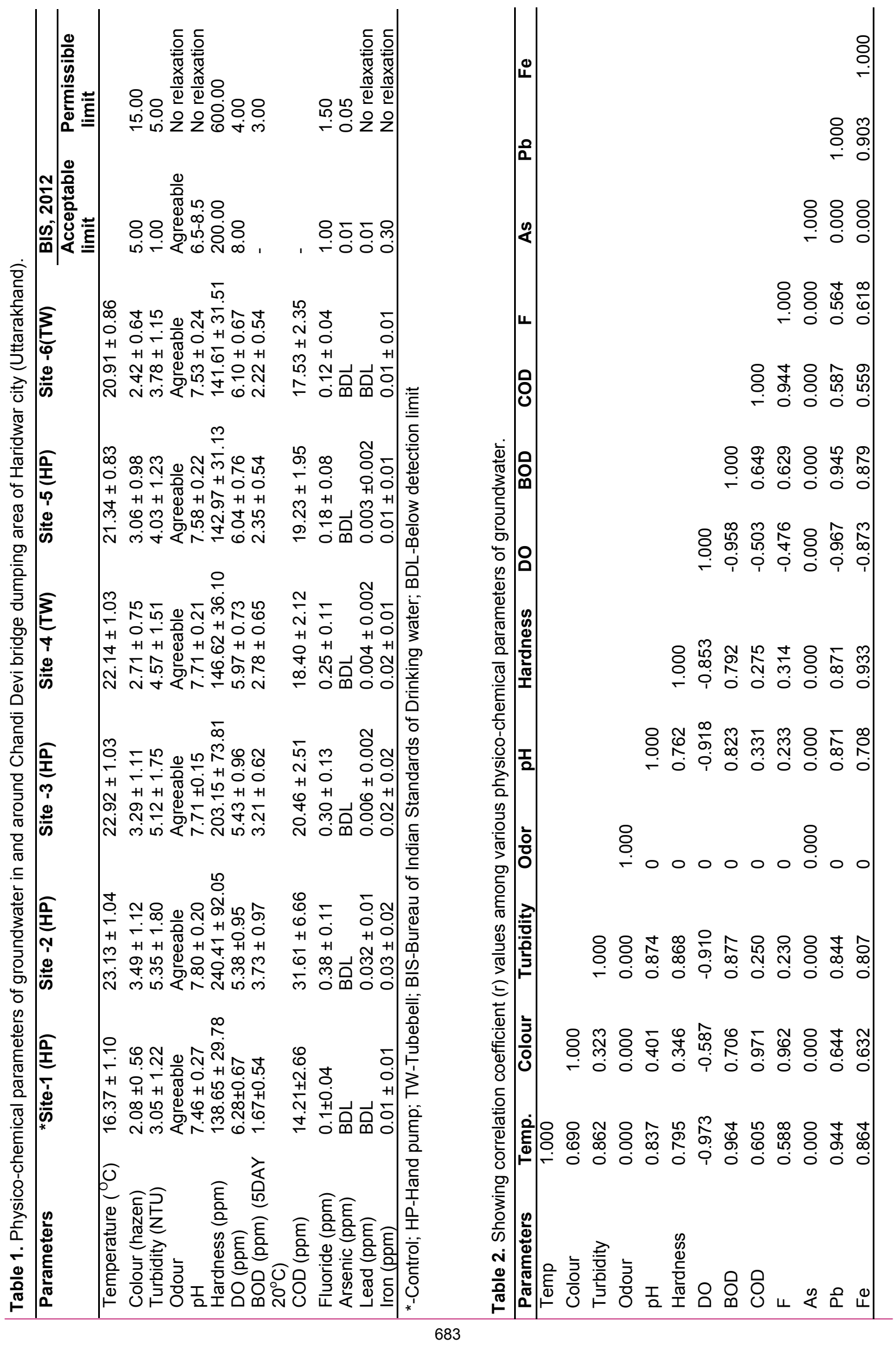




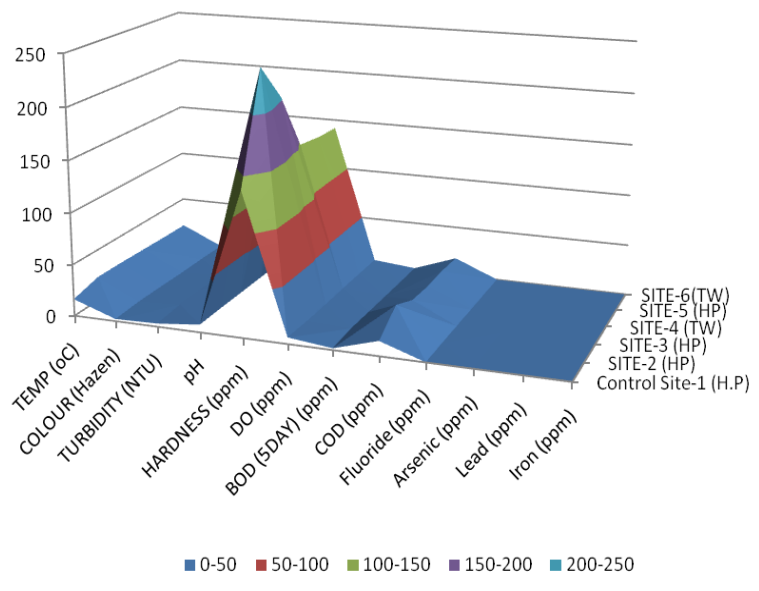

Fig. 2. Showing variations among physicochemical parameters of ground water of different sites of Chandi bridge and the control site (near Bilkeshwar temple).

trol (site 1) are given in Table-1 and the correlation $(r)$ values among different parameters are shown in Table-2. Fig.2 shows variations among physicochemical parameters of ground water samples of different sites.

Temperature: Its measurement is useful to determine the trends of biochemical and biological activities in aquatic ecosystem. The growth of organisms and microorganisms are enhanced by warm water conditions and can lead to the development of unpleasant taste and odour (Sacramento, 1963). While Lalitha et al., (2003) studied that the temperature of water ranging from $7{ }^{\circ} \mathrm{C}$ to $11^{\circ} \mathrm{C}$ is pleasant and refreshing in nature and Edo et al. (2014) reported temperature of ground water in the range of $26-26.90^{\circ} \mathrm{C}$ in Igwuruta at Nigeria. In the present study it was observed that the ground water of all the experimental sites had higher temperature value $\left(20.91\right.$ to $\left.23.13^{\circ} \mathrm{C}\right)$ than control site $\left(16.37^{\circ} \mathrm{C}\right)$ bilkeshwar temple. The site -2 had higher temperature $\left(23.13^{\circ} \mathrm{C}\right)$ among all experimental sites which may be due to higher pollutant load at this site. The correlation ( $r$ ) among different parameters with the temperature showed that temperature was negatively correlated with DO (-0.973). The increase in temperature increases the dissociation of oxygen and increases the growth of microorganism which also consumes the oxygen for their survival. Therefore, the municipal waste dumping may have a negative effect on the temperature of ground water.

Colour: It is the onsite indicator for potability of water and may result from the presence of natural metallic ions (iron and manganese). Royee and Prakasam (2003) observed higher range (12.5 hazen to 15 hazen) of colour in tube well water at Kollam municipality, Kerala, while Mahesha and Prasad (2004) noticed the lower range (1.3 hazen to 4.0 hazen) of colour near Arsikere Taluk at Karnataka than the present studied values of colour
(2.42 to 3.49 hazen) in ground water of all the experimental sites. Although the observed range of colour was under the desirable range of BIS but mean value at site-2 (3.49 hazen) was quite higher and may cross the desirable limit in future. This may be due to presence of higher dissolved organic matter and salt concentration in the ground water at experimental sites, which might have increased the hardness as well as turbidity, thereby increasing the colour.

The correlation coefficient (r)among different parameters with the colour showed that colour was positively correlated with temperature $(+0.690)$ and $\mathrm{pH}(+0.401)$ at experimental sites. Andrew (1995) stated that the colour of water is extremely $\mathrm{pH}$ dependent and invariably increases as the $\mathrm{pH}$ of water is raised. The positive correlation of colour with temperature showed that as the temperature increased, the microbial decomposition of organic material might also increase thereby increasing the colour of the ground water. Thus, the municipal waste may influence the colour of ground water adversely.

Turbidity: Roy (2004) observed the turbidity of water ranging from 0.4 NTU to 5.6 NTU near NCC office at Kollam Municipality, Kerala, while Deshpande et al. (2005) found the range of turbidity (4.6 NTU to $6.5 \mathrm{NTU}$ ) at Ramtek Tehsil, Nagpur. Sahni et al. (2010) reported higher value of turbidity which may be due to leaching of toxic substances of municipal solid waste into the ground water. Mishra et al. (2013) reported higher turbidity range from 9.6 to 32.8 NTU in Jharpada and other sites at Odisha. In the present study it was observed that the experimental sites had higher turbidity value (3.78 to $5.35 \mathrm{NTU}$ ) than the control site (3.05 NTU) bilkeshwar temple which may be due to higher degree of precipitates of $\mathrm{Ca}$ and $\mathrm{Mg}$. The detected range of turbidity were under the desirable limit of BIS It may due to presence of organic material coming from the leaching of the waste which not only increases the turbidity but also affect the other parameters.

The presence of higher suspended impurities in ground water at site-2 may due to less distance from dumping site and higher leaching of soluble impurities from waste. These impurities proliferate downwards and remain on the superficial layer of water. Therefore, it may be said that higher dumping of municipal waste also has a detrimental effect on turbidity of ground water.

The correlation study revealed that turbidity was directly proportional to the suspended and dissolved solids present in ground water which may absorb and reflect the light back to the surrounding thereby interfering the movement of light and affects the colour of water positively ( $r=+0.323)$.

Odour: The odour may be of natural origin caused by living and decaying aquatic organisms and accumulation of gasses like ammonia and 
hydrogen sulphide (Asthana and Asthana, 2004). In the present study, odour was unobjectionable at all the experimental dumping sites of Chandi bridge, Hardwar which may be due to higher dilution from surface water body.

pH (Hydrogen ion concentration): $\mathrm{pH}$ plays an important role in the growth of microbial activity. As specific microorganism carryout optimum activity related with degradation of organic components in a particular range of $\mathrm{pH}$ and change in $\mathrm{pH}$ may adversely affect microbial activity of that particular aquatic ecosystem. Govardhan (1990) observed the $\mathrm{pH}$ range of ground water 6.2 to 8.9 in Nalgonda at Telangana. Mohammad et al. (2002) reported that $\mathrm{pH}$ tends to increase from summer to winter which may be due to depletion in readily biodegradable organics in ground water. Royee and Prakasam (2003) observed the $\mathrm{pH}$ range 7.36 to 7.49 in tube well water near Kollam Municipality at Kerala. Panda et al. (2004) found the basic $\mathrm{pH}$ range (7.1 to 8.1 ) in wet season at garbage dumping site of Palasuni villge and other places at Bhuvaneswar. The present study also observed that the experimental sites had higher and basic range of $\mathrm{pH}$ (7.53 to 7.80) than control site (7.46) which may be due to presence of more salts in the water at experimental sites. The studied values of $\mathrm{pH}$ are within desirable range of BIS. Almost similar value of $\mathrm{pH}$ has been detected by Gautam et al. (2011) at municipal waste dumping site Sewapura at Jaipur. The present study revealed that basic range of ground water at experimental sites might be due to presence of anions like $\mathrm{OH}^{-}, \mathrm{CO}^{--}$and $\mathrm{HCO}^{-}$which are also responsible for higher alkalinity of ground water.

Yadav and Lata (2003) have noticed the positive correlation in between $\mathrm{pH}$ and electrical conductivity at Bahadurgarh block Jhajjar, Haryana. In the present study correlation coefficient ( $r$ ) among different parameters with the $\mathrm{pH}$ showed that $\mathrm{pH}$ was positively correlated with turbidity $(+0.874)$. It may due to that at the basic $\mathrm{pH}$, the salts or the anions increase with the result the turbidity and electrical conductivity of ground water also increases. Therefore, the dumping of municipal waste may increase the $\mathrm{pH}$ of water and helps to change the taste of ground water.

Total hardness: Subba Rao (1998) observed that higher values of $\mathrm{Ca}$ and $\mathrm{Mg}$ have a positive impact on eutrophication in ground water (well water). Panda et al. (2004) observed the higher value of calcium and magnesium species in wet season than the summer. Mahesha and Prasad (2004) observed slightly lower hardness (range 170 to $410 \mathrm{mg} / \mathrm{l}$ ) near Arsikere at Karnataka. Deshpande et al. (2005) noticed hardness range 264 ppm to 319 ppm at Ramtek Tehsil, Nagpur. Kurakalva et al. (2016) found higher value of total hardness $(\mathrm{TH})$ of groundwater samples from 120 to $525 \mathrm{mg} / \mathrm{L}$ at Jawaharnagar municipal solid waste dumping site at greater Hyderabad. In the present study the total hardness of all experimental sites were within the desirable range of BIS but it was observed that the experimental sites had higher total hardness (141.61 to 240.41 ppm) than control site (138.65 ppm) which may be due to leaching of higher $\mathrm{Ca}$ and $\mathrm{Mg}$ species from waste affected soil in the ground water of the experimental sites. The $\mathrm{Ca}$ and $\mathrm{Mg}$ species increase due to contamination of acidic leachate when the leachate reacts with soil having abundant calcium and magnesium. The cations tend to move with leachate and reaches in to the ground water. This mechanism enhances the formation of carbonates of $\mathrm{Ca}$ and $\mathrm{Mg}$ in ground water thereby increasing the hardness of ground water. Taste of water is also dependent upon the presence of $\mathrm{Ca}^{++}$rather than $\mathrm{Mg}^{++}$. The correlation among different parameters with the hardness showed that hardness was positively correlated with $\mathrm{pH}(\mathrm{r}=+0.762)$ and turbidity $(+0.874)$ at all the experimental sites. The hardness of ground water increased as the turbidity increased. It may be due to higher precipitation of $\mathrm{Ca}$ and $\mathrm{Mg}$ carbonates in soil that leached to the ground water and increased the hardness of water.

Dissolved oxygen (DO): Sangodoyin and Agbawhe (1992) reported DO values ranging from 5.1 to $5.6 \mathrm{ppm}$ in well water near the dumping site of Abattoir effluents at Ibadan, Nigeria. Mahesha and Prasad (2004) observed DO range (6.22 to $6.48 \mathrm{ppm}$ ) of bore well water at Arsikere taluk, Karnataka. Edo et al. (2014) noticed DO in the range of 5.20 to $6.30 \mathrm{ppm}$ in Igwuruta at Nigeria. In the present study the values of DO at all experimental sites did not match the desirable limits of BIS. The experimental sites had lower DO range from 5.38 to $6.1 \mathrm{ppm}$ than control site $(6.28 \mathrm{ppm})$ which may be due to presence of higher oxygen consuming ingredients in the ground water at experimental sites. It may due to presence of higher organic and biological load in ground water which may be released from the leachate of degradable waste thereby decreasing the DO value of ground water at solid waste dumping site.

The correlation coefficient $(r)$ among different parameters with the DO showed that DO was negatively correlated with temperature $(r=-0.973)$ and turbidity $(-0.910)$ at all the experimental sites. This may be due to an increase in temperature which increases the dissociation of oxygen and increases the growth of microorganisms that also consume the oxygen for their survival. The higher amount of organic matter, silt and $\mathrm{Ca} / \mathrm{Mg}$ increases the turbidity of ground water thereby decreasing the DO value by consuming most of its part during their stabilization. Thus, it may be said that higher dumping of municipal waste decreased the DO level in ground water which may be harmful for aquatic life and may produce obnoxious odour. 
BOD: Mahesha and Prasad (2004) observed higher range of BOD (4 to $5 \mathrm{ppm}$ ) at Hasan, Karnataka. Edo et al. (2014) reported BOD range from 1.20 to $4.6 \mathrm{ppm}$ in Igwuruta at Nigeria. The present study observed that the values of BOD at experimental site-2 and site-3 were quite higher than permissible range of BIS while rest experimental sites were within permissible range of BIS. All the experimental sites had higher BOD (2.22 to $3.73 \mathrm{ppm}$ ) than control site (1.67 ppm) which may be due to presence of organic impurities in ground water which requires more oxygen in its decomposition by aerobic bacteria. The aerobes may decompose the organic matter and utilize most of the dissolved oxygen. These organic impurities may easily enter into ground water with leachate, originated from solid waste dumping site thereby increasing the BOD of ground water during their microbial decomposition.

The correlation among different parameters with the BOD showed that BOD was negatively correlated with $\mathrm{DO}(\mathrm{r}=-0.958)$ and positively correlated with the temperature $(r=+0.964)$ at all the experimental sites. This study showed as the microbial population increased, the temperature also increased and enhanced the degradation of organic matter present in ground water near solid waste dumping site.

COD: Aurangabadkar et al. (2001) observed the range of COD (12 to $40 \mathrm{mg} / \mathrm{l}$ ) near Perungudi dumpsite at Chennai while Ikem et al. (2002) observed the lower value (0.62 ppm) in dry season and $(6.03 \mathrm{ppm})$ in rainy season near Ibadan, Nigeria. Edo et al. (2014) noticed lower range of COD (2.10 to $7 \mathrm{ppm}$ ) in Igwuruta at Nigeria. In the present study it was observed that the experimental sites had higher COD value (17.53 to $31.61 \mathrm{ppm})$ than control site (14.21 ppm), which may be due to presence of organic impurities in ground water. It may be due to acidic nature of rain water that have higher solubility of inorganic and organic impurities present at dumping soil and also lesser density of soil particles through which these impurities percolates and reaches to ground water increases the COD value of ground water and ultimately decrease the DO present in ground water and may affect its portability.

The correlation coefficient ( $r$ ) among different parameters with the COD showed that COD was positively correlated with colour $(r=+0.971)$ and negatively correlated with the DO $(r=-0.503)$ at all the experimental sites. The presence of higher amount of inorganic and organic compounds in ground water near solid waste dumping site which may increase the colour and affect the COD value. The consequences of increase in COD value result in downfall of $\mathrm{DO}$ thereby showing negative correlation of COD with the DO and positive correlation with the colour gradient of ground water.

Fluoride: Occurrence of fluoride has drawn world- wide attention due to considerable impact on human physiology (Kundu et al. 2001). About 115.3 lakh Indian population is at risk based on population in habitations with high fluoride in drinking water (DGHS, 2016). Royee and Prakasam (2003) observed slightly higher fluoride range of 0.66 to $0.72 \mathrm{ppm}$ at Kollam municipality, Kerala. Kumar et al. (2015) has observed higher Fluoride ( 0.56 to $0.76 \mathrm{mg} / \mathrm{l})$ during pre-monsoon and from 0.44 to $0.88 \mathrm{mg} / \mathrm{l}$ during post monsoon at Thiruvananthapuram. The present study showed that though fluoride content at all experimental sites were within desirable range of BIS, the experimental sites had higher fluoride value $(0.12$ to $0.38 \mathrm{ppm})$ than control site $(0.1 \mathrm{ppm})$ which may be due to presence of fluoride contamination from percolation of leachate. This leachate may be enriched with fluoride due to dumping of cloth products having dyes and coloring agents.These cloth articles are highly demanded during festival season of Kanvar yatra during of Mahashivratri in Haridwar. The correlation coefficient ( $r$ ) among different parameters with the fluoride content showed that fluoride was negatively correlated with DO $(r=-0.476)$ and positively correlated with the COD $(r=+0.944)$ and temperature $(r=+0.588)$ at all the experimental sites. The correlation study gave a clear indication that fluoride was directly proportional to temperature and COD while inversely proportional to $\mathrm{DO}$. As the temperature increased, the formation of oxides, other constituents of fluoride may also be increased. During this process, the COD value showed sharp increase and DO value showed sharp downfall because the oxides formation may consume most of the D.O Thus the presence of more fluoride in ground water may have increased the C.O.D of water.

Arsenic: It has a tendency to get accumulated in body tissue to cause arsenosis and may have an adverse effect on liver, heart, and is also reported as carcinogenic (Saha et al.,2010), Arsenic has been associated with a variety of complications in body organ systems that may be integumentary, nervous, respiratory, cardiovascular, hematopoietic, immune, endocrine, hepatic, renal, reproductive system (Khaja et al., 2015) As per the WHO the maximum permissible limit of arsenic in ground water is $0.05 \mathrm{mg} / \mathrm{L}$. In the present observation, arsenic $(0.00 \mathrm{ppm})$ was not detected and thus did not influence the water quality significantly.

Lead: It is also a toxic element and accumulates in the body mainly in the bones. Chronic exposure of lead can result in mental retardation, birth defects, psychosis, autism, allergies, dyslexia, weight loss, hyperactivity, paralysis, muscular weakness, brain damage, kidney damage and may even cause death (Martin and Griswold, 2009). Aurangabadkar et al. (2001) observed the lead range 0.05-0.06 ppm at west of 
Perungudi dumpsite at Chennai and Ikem et al. (2002) noticed the lower range of lead (0.01to $0.03 \mathrm{ppm}$ ) in ground water at Ibadan, Nigeria. Lower value of lead was also observed by Patil et al. (2013) at Karnataka and quite the same value of lead has been detected by Edo et al. (2014) in Igwuruta at Nigeria. The present observation also showed lower range of lead at all experimental sites as per BIS and the values were within the permissible range. However, it was also observed that all experimental sites had higher lead content ( 0.000 to $0.032 \mathrm{ppm})$ than the control site $(0.000$ ppm) Bilkeshwar temple which may be due to the presence of paint remains in leachate coming from printed articles which are generally used in various festivals and its trash reached to disposal sites. The correlation coefficient $(r)$ among different parameters with the lead content showed that lead was positively correlated with temperature $(r=+0.944)$ and with COD $(r=+0.587)$ at all the experimental sites. The correlation study gave an indication that lead was directly proportional to temperature and COD as the temperature of ground water increased the lead content also increases and thereby consuming more oxygen in stabilization and increasing the COD value of ground water. This may be due to disposal of discarded batteries that may have increased the leaching of lead towards ground water. Therefore, the dumping of municipal waste increases the lead content in ground water, which may pose serious health hazards.

Iron: Iron in ground water is often noticeably orange in colour, causing discoloration of laundry and has an unpleasant taste. Aurangabadkar et al. (2001) observed the iron content (range 0.6 to $3.86 \mathrm{ppm}$ ) near Perungudi at Chennai while Ikem et al.(2002) noticed iron range (1.05 to $4.6 \mathrm{ppm}$ ) at Ibadan, Nigeria. Edo et al. (2014) noticed iron range (2.00 to $4.40 \mathrm{ppm}$ ) Igwuruta at Nigeria. Panda et al. (2004) observed the value of iron ranged from 0.09 to $2 \mathrm{ppm}$ during dry season in ground water sample of Palasuni village at Bhubaneswar city. Shenbagarani (2013) reported quite same range of iron $(0.01-1.5 \mathrm{ppm})$ in ground water sample of Perungudi and Kodunganyur at Chennai Tamilnadu. The present study observed that iron content at all experimental sites were within permissible range of BIS. This study indicates that all experimental sites had higher iron content $(0.01$ to $0.03 \mathrm{ppm})$ than control site $(0.01$ ppm) which may be due to presence of Iron bacteria which helps to oxidize ferrous salts present in ground water in to ferric salts that also reduces oxygen condition and makes anodic region in iron pipes while exposed region act as cathodic region this phenomenon corrodes iron pipes, used in bore well and hand pumps. Although $\mathrm{Fe}^{++}$is generally not harmful for living species but $\mathrm{Fe}^{+++}$is poisonous for living species. Also these cations deposited on the clothes material and may be responsible for destruction of textile fiber. Iron bacteria also help to produce slime on the wall of water storage structure. The correlation coefficient ( $r$ ) among different parameters with the iron content showed that iron was positively correlated with temperature $(r=+0.864)$ and turbidity $(r=+0.807)$ at all the experimental sites. The correlation study gave a clear indication that iron is directly proportional to temperature and turbidity. This may be due to higher salts concentration which may enhance the rust formation and thus increasing the iron content and turbidity in ground water samples by dumping of municipal waste.

The data analysis further revealed that in the present study, DO was found to increase while BOD and COD decreased as the distance of water source increased from dumping site (Fig.-2). DO was comparatively higher while $B O D$ and $C O D$ were lower in tubewell water than handpump water due difference in the depth of both the water sources. This indicated the availability of more pollutants on the upper surface of ground water that affected ground water quality of hand pump more than the ground water quality of tubewell. The lower range of fluoride indicated that the fluoride content is also affected by dilution of surface water body running near to the dumping area. The presence of these anions indicated that these charges cannot be trapped by soil sediments and proliferate through leachate and enter in to ground water. The lower range of lead and iron content in ground water samples revealed low availability of lead and iron trash in municipal waste sites as these metals are economically important and picked by ragpickers from the dumping site. However, the higher concentration of lead and iron at the site-2 may be due to that it was closer to dumping area and the pollutants may increase here with an alarming rate.

\section{Conclusion}

In was concluded that groundwater quality of the areas around municipal waste dumping site (Sites 2 to Sites 6 of Chandi bridge, Haridwar city (Uttarakhand), had higher values of the physicochemical parameters viz. turbidity, $\mathrm{pH}$, hardness, BOD, COD, fluoride, lead and iron than the area taken as control site-1. The waste disposal source was dominated over in the vicinity of Site-2 result- 
ing in higher values of parameters viz temperature, colour, turbidity, $\mathrm{pH}$, hardness, BOD, COD, fluoride, lead and iron than the other dumping sites. The higher COD value of site- 2 showed presence of higher chemical impurities in ground water quality. Therefore ground water of site-2 is more contaminated than other experimental sites. The heavy metals (arsenic, lead, iron) and other parameters like temperature, colour, $\mathrm{pH}$, hardness, fluoride except turbidity of site-2, 3 and DO, $\mathrm{BOD}$ in all the ground water samples were found within the permissible limits of BIS and may be considered safe for drinking purpose which may due to higher infiltration rate of water from nearby surface water source, river Ganga and eastern Ganga canal. This infiltration may have positive effect on dilution of polluted ground water that makes ground water fit for drinking purpose. The present study would be helpful for taking timely measures to prevent contamination of the groundwater quality of the areas near the dumping site.

\section{ACKNOWLEDGEMENTS}

The author thanks to The Head, Department of Zoology and Environment Science, Gurukula Kangri University, Haridwar (Uttarakhand) for providing necessary facilites. Thanks are also due to The Director of Ajay Kumar Garg Engineering College, Ghaziabad (Uttar Pradesh) for his constant encouragement for the research work.

\section{REFERENCES}

Andrew, D., Eaton, Lenore, S., Clesceri and Arnold, E., Greenberg (1995). Standard methods for the examination of water and wastewater. American Public Health Association, 1015, Fifteenth Street, NW Washington, D.C, 2005.

APHA (2005).Standard methods for the examination of water and waste water, American Public ealth Association, $19^{\text {th }}$ edition, 1015, Fifteenth Street, NW, Vol.1 (1),: 10-150.

Asthana,D.K and Asthana, Meera (2004).A text book of environmental studies, pp-187, S.Chand publication New Delhi ISBN-81-219-2764-1

Aurangabadkar, K., Swaminathan, K., Sandhya, S., Uma, T.S, Jothikumar, N. and Paramasivam, R. (2001). Ground water quality around a municipal solid waste dump site at Chennai. I.J.E.P.Vol. 21(4),: 323-327.

Berner-Kay, E., Berner, R.A. (1987). The global water cycle, geochemistry and environment. englewood Cliffs: Prentice Hall (396pp)

BIS (2012) . Bureau of Indian Standrads Manak Bhavan 9, Bahadur Shah Zafar Marg New Delhi- 110002

Central Pollution Control Board (CPCB) (2015). Consolidated annual review report prepared in compliance to the provision 8(2) of the MSW Rules, 2000, India: Ministry of Environment and Forest, New Delhi.

Census (2011).Population census of city Retrieved from www.census2011.co.in/city.php

Dermatas, D, Mpouras, T, Chrysochoou, M. (2015). Origin and concentration profile of chromium in a Greek aquifer. Journal of Hazardous Materials.
Vol.281,: 35-46.

Dermatas, D. and Panagiotakis, I (2012). Encyclopedia of Sustainability Science and Technology. In: Meyers, RA (ed.). Remediation of contaminated soil. New York, USA: Springer-Verlag, :2430-2454.

Deshpande Leena, Tahcker Neeta, Ghosh Chandana, Singh Kumari Sandhya and Madan Nanoti (2005). Water quality status of Murda village in Ramtek tahsil. J. of Env.Sci.and Engg. Vol.47(2),: 161-163.

DGHS (2016). http://dghs.gov.in content/1355_3_ NationalProgrammePreventionControl.aspx

Edo, F. A, C. C. Ejiogu, A. P. Uzoije, M. A. Nwachukwu and C. G. Okoli (2014). Impact of Open Sewage Dumpsites on Groundwater Quality in Igwuruta, Rivers State, Nigeria journal of global biosciences issn 2320-1355.Vol. 3( 6),: 919-930

Gautam A, Pathak G, Sahni A. (2011) Assessment of ground water quality at municipal solid waste dumping Site-Sewapura, Jaipur. Curr World Environ. Vol. 1 (6), : 279-282.

Govardhan, V. (1990). Ground water pollution hazardous to human life- A case study of Nalgonda district. I.J.E.P. Vol.10 (1), : 54-61.

Karthika, Ignatius Navis , Thara, K and Dheenadayalan, M.S. (2018). Physico-chemical study of the ground water quality at selected locations in Periyakulam, Theni district, Tamilnadu, India. Materials Today Proceedings Vol. 5 ( 1-1),: 422-428.

Khaja Shameem Mohammed Abdul, Sudheera Sammanthi Jaysinghe,Ediriweera P.S. Chandana, Channa Javasumana, P.Mangala C.S. De Silva (2015) Arsenic and human health effects: A review, Environmental Toxicology and Pharmacology, Vol. 40 (3), 828-846.

Ikem, A., Osibanjo, O., Sridhar, M.K.C. and Sobande, A. (2002). Evaluation of ground water quality characteristics near two waste sites in Ibadan and Lagos, Nigeria. Water, Air and Soil pollution.Vol. 140, : 307 333.

Krcmar Dejan, Tenodi Slaven,Nenad Grba, Kerkez Djurdja, Watson Malcolm, Rončević Srdjan, Dalmacija Božo (2018). Preremedial assessment of the municipal landfill pollution impact on soil and shallow groundwater in Subotica, Serbia Science of The Total Environment Vol. 615, : 1341-1354.

Kumar Anju Anil, Dipu Sukumaran, Salom Gnana Thanga Vincent (2015). Effect of municipal solid waste leachate on ground water quality of Thiruvananthapuram District, Ker. Applied Ecology and Environmental Sciences. Vol. 3(5),: 151-157.

Kundu, N., Panigrahi, M.K., Tripathy, S., Munshi, S., Powell, M.A., Haul, B.R.(2001).Geochemcial appraisal of fluoride contamination of groundwater in the Nayagarh district of Orissa, India. Environmental Geology.Vol. 41,: 451-460.

Kurakalva R.M, .Aradhi, K.K, .Mallela, K.Y and Venkatayogi, S. (2016). Assessment of groundwater quality in and around the Jawaharnagar municipal solid waste dumping site at greater Hyderabad, southern India procedia Environmental Sciences.Vol. 35,: 328 -336 .

Lalitha, S., Kasthuri, R., Kalaivani, D., Banumathi, K. and Akilandeshwari, L. (2003). Impact of sewage disposal on quality of water near Chinthamani, Tiruchirapalli, I.J.E.P. Vol. 23 (11),:1268-1271.

Lenntech Water Treatment and Air Purification (2004). Water Treatment. Published by Lenntech, 
Rotterdamseweg. Available online at: www.excelwater.com/thp/filters/WaterPurification.htm

Mahesha Nagraja Naik and Rajendra Prasad, N.R. (2004). Physicochemical characteristics of bore well water in Arsikere Taluk, Hassan. I.J.E.P. Vol. 24 (12),: 897-904.

Martin, S., Griswold, W. (2009). Human health effects of heavy metals. Environmental Science and Technology Briefs for Citizens. (15):1-6.

Mishra Swopna, Kumar Mohanty Saswat and Prakash Swoyam (2013). Physicochemical analysis of ground water near municipal solid waste dumping site in Bhubaneswar municipal corporation, Odisha.IJPAES, Vol. 3(3),: 5-16.

Mohammad Zafar, Kumar Dinesh and Alappat, B.J. (2002). Charactersitcs of leachate from a MSW land fill in Delhi. Ind.J. Env.Prot. Vol. 22(10),: 1120-1126.

National Ground Water Association (NGSA) (2016) Facts About Global Groundwater Usage. Ohio, USA: National Ground Water Association.

Panda, S.P., Mishra, C.S.K., Muduli, R., Behera, D.K. and Jung, Wk, Kim (2004). Water quality assessment for wells located near municipal waste dumping sites in Bhubaneswar city, India. Environmental Book, Vol.42.

Patil Chidanand, Narayanakar Shreekant and Virupakshi Arjun (2013). Assessment of groundwater quality around solid waste landfill area, International Journal of Innovative Research in Science, Engineering and Technology Vol. 2 (7),:3131-3136.

Roy, M.K.P.(2004) Review of Studies http:// www.krpcds.org/publication/downloads/56.pdf.
Royee, M.K.P. and Prakasam, V.R. (2003). Water characteristics of dug and tube wells of kollam municipality. I.J.E.P. Vol.23 (6),: 607-612.

Shenbagarani, S. (2013). Analysis of groundwater quality near the solid waste dumping site at Tamilnadu, Journal Of Environmental Science, Toxicology And Food Technology) e-ISSN: 2319-2402,p- ISSN: 2319 -2399. Vol.4 ( 2 ), :01-05.

Sacramento, C.A. (1963). In.Water quality criteria $2^{\text {nd }}$ ed. Callifornia state water quality control board: 283.

Sahni Kavita., Sahni Anirudh., and Gautam Abhishek. (2010) Assessment of Drinking Water Quality of Jaipur Main and its Various Suburb Railway Stations with Special Mention to Fluoride, Current World Environment.Vol.5(2),: 293-298

Saha, J.C., Dikshit, A.K., Bandopadhyay, M., Saha, K.C. (2010). Review of Arsenic poisoning and its effects on human health. Critical Reviews in Environmental Science and Technology Vol. 29, :281-313.

Sangodoyin, A.Y. and Agbawhe (1992). Environmental study on surface and groundwater pollutants from abattoir effluents. Biores. Tech. 41:193-200.

Soujanya, B. Kamble (2016). Characterization of leachate and its effects on ground water quality around Jawaharnagar municipal open dumpsite, Rangareddy, Telangana, Current World Environment Vol. 11(1),: 114-125.

Subba Rao (1998). A manual of practical methods in environmental sciences. Andhra University Visakhapatnam: 32.

Yadav, J.P. and Lata, Suman (2003). Pollution of fluoride in ground water in Bahadurgarh block of district Jhajjar, Haryana. I.J.E.P., 23 (6),: 680-686. 